\title{
Formaldehyde over the eastern Mediterranean during MINOS: Comparison of airborne in-situ measurements with 3D-model results
}

\author{
R. Kormann ${ }^{1}$, H. Fischer ${ }^{1}$, M. de Reus ${ }^{1}$, M. Lawrence ${ }^{1}$, Ch. Brühl ${ }^{1}$, R. von Kuhlmann ${ }^{1}$, R. Holzinger ${ }^{1}$, J. Williams ${ }^{1}$, \\ J. Lelieveld ${ }^{1}$, C. Warneke ${ }^{2}$, J. de Gouw ${ }^{2}$, J. Heland ${ }^{3}$, H. Ziereis ${ }^{3}$, and H. Schlager ${ }^{3}$ \\ ${ }^{1}$ Max-Planck-Institut für Chemie, J.J. Becher-Weg 22, 55128 Mainz, Germany \\ ${ }^{2}$ NOAA Aeronomy Laboratory, 325 Broadway, Boulder, CO, USA \\ ${ }^{3}$ Institut für Physik der Atmosphäre, DLR, Oberpfaffenhofen, 82230 Wessling, Germany
}

Received: 7 February 2003 - Published in Atmos. Chem. Phys. Discuss.: 10 March 2003

Revised: 16 June 2003 - Accepted: 18 June 2003 - Published: 23 June 2003

\begin{abstract}
Formaldehyde (HCHO) is an important intermediate product in the photochemical degradation of methane and non-methane volatile organic compounds. In August 2001, airborne formaldehyde measurements based on the Hantzsch reaction technique were performed during the Mediterranean INtensive Oxidant Study, MINOS. The detection limit of the instrument was $42 \mathrm{pptv}(1 \sigma)$ at a time resolution of $180 \mathrm{~s}$ $(10-90 \%)$. The overall uncertainty of the HCHO measurements was $30 \%$ at a mixing ratio of 300 pptv. In the marine boundary layer over the eastern Mediterranean Sea average $\mathrm{HCHO}$ concentrations were of the order of $1500 \mathrm{pptv}$, in reasonable agreement with results from a three-dimensional global chemical transport model of the lower atmosphere including non-methane volatile organic compound (NMVOC) chemistry. Above the boundary layer $\mathrm{HCHO}$ mixing ratios decreased with increasing altitude to a minimum level of $250 \mathrm{pptv}$ at about $7 \mathrm{~km}$. At higher altitudes (above $7 \mathrm{~km}$ ) HCHO levels showed a strong dependency on the airmass origin. In airmasses from the North Atlantic/North American area HCHO levels were of the order of $300 \mathrm{pptv}$, a factor of 6 higher than values predicted by the model. Even higher $\mathrm{HCHO}$ levels, increasing to values of the order of $600 \mathrm{pptv}$ at $11 \mathrm{~km}$ altitude, were observed in easterlies transporting air affected by the Indian monsoon outflow towards the Mediterranean basin. Only a small part ( $\sim 30 \mathrm{pptv})$ of the large discrepancy between the model results and the measurements of $\mathrm{HCHO}$ in the free troposphere could be explained by a strong underestimation of the upper tropospheric acetone concentration by up to a factor of ten by the 3D-model. Therefore, the measurement-model difference in the upper troposphere remains unresolved, while the observed dependency of $\mathrm{HCHO}$ on airmass origin might indicate that unknown, relatively long-lived NMVOCs - or their reaction intermedi-
\end{abstract}

Correspondence to: H. Fischer (hofi@mpch-mainz.mpg.de) ates - associated with biomass burning are at least partially responsible for the observed discrepancies.

\section{Introduction}

Formaldehyde ( $\mathrm{HCHO})$ is a major intermediate reaction product in atmospheric photochemistry. Additional sources are direct emissions from incomplete fossil fuel combustion (de Serves, 1994; Sigsby et al., 1987), biomass burning (Lee et al., 1997), industrial processing, and emissions from vegetation (Carlier et al, 1986, and references therein). It is produced during the photochemical degradation of methane and non-methane volatile organic compounds (NMVOC), with methane chemistry being a dominant source of $\mathrm{HCHO}$ in the free troposphere and the remote marine boundary layer (Lowe and Schmidt, 1983). Reactions of HCHO with the hydroxyl radical $(\mathrm{OH})$ and two wavelength dependent photolytic channels (yielding $\mathrm{H}_{2}+\mathrm{CO}$ at $\lambda$ greater than $325 \mathrm{~nm}$ or $\mathrm{H}+\mathrm{HCO}$ at $\lambda$ less than $325 \mathrm{~nm}$ ) are the main loss processes. Losses through dry deposition or rain may also be significant. Typically the photochemical lifetime of $\mathrm{HCHO}$ near the surface in the sunlit atmosphere is of the order of $4 \mathrm{~h}$ (Lowe and Schmidt, 1983) decreasing with increasing altitude due to enhanced photolysis rate. Since HCHO production and destruction depend on $\mathrm{OH}$ radical concentrations and the solar photon flux, its concentration can be used as an indicator of photochemical activity and of the role of NMVOC in the background atmosphere (Lowe and Schmidt, 1983). In particular in the upper troposphere, HCHO measurements can be used to assess the role of oxygenated hydrocarbons on the $\mathrm{HO}_{\mathrm{x}}$ budget (Crawford et al., 1999).

In the remote marine boundary layer levels of HCHO exceed 100-200 pptv (Zafirou et al., 1980; Lowe and Schmidt,

(C) European Geosciences Union 2003 
1983; Arlander et al., 1990; Heikes, 1992; Harris et al., 1992; Zhou et al., 1996; Mackay et al., 1996; Jacob et al., 1996; Ayers et al., 1997; Jaeglé et al., 2000; Weller et al., 2000; Wagner et al., 2001), and they decrease with increasing altitude in the free troposphere (Arlander et al., 1995; Jacob et al., 1996; Jaeglé et al., 2000; Heikes et al., 2001; Fried et al., 2002; Fried et al., 2003). These measurements have been compared to model simulations based on simple steady state expressions (Arlander et al., 1995; Zhou et al., 1996), box models (Liu et al., 1992; Jacob et al., 1996; Ayers et al., 1997; Jaeglé et al., 2000; Weller et al., 2000; Heikes et al., 2001; Frost et al., 2002; Wagner et al., 2002; Fried et al., 2003), two-dimensional (2D) (Lowe and Schmidt, 1983; Arlander et al., 1995), and 3D models (Brasseur et al., 1996; Hauglustaine et al., 1998; von Kuhlmann et al., 2003b). Although in some cases the models show good agreement with the HCHO observations, significant discrepancies are found frequently (Lowe and Schmidt, 1993; Liu et al., 1992; Arlander et al., 1995; Zhou et al., 1996; Jacob et al., 1996; Ayers et al., 1997; Jaeglé et al., 2000; Weller et al., 2000; Heikes et al., 2001; Frost et al., 2002). For the marine boundary layer overestimation (Lowe and Schmidt, 1993; Jacob et al., 1996) as well as underestimation (Ayers et al., 1997; Weller et al., 2000) of the HCHO concentrations by models are not well understood. For the middle and upper free troposphere, models tend to systematically underestimate the $\mathrm{HCHO}$ concentrations (Arlander et al., 1995; Hauglustaine et al., 1998; Jaeglé et al., 2000; Heikes et al., 2001; Frost et al., 2002). More recent studies in the marine boundary layer by Wagner et al. (2001) and in the free troposphere by Fried et al. (2003) achieved very good measurement-model agreement. Here we present airborne in-situ measurements of $\mathrm{HCHO}$ and its precursors in the marine boundary layer and free troposphere over the eastern Mediterranean basin. The observations were made during 14 measurement flights of the German research aircraft Falcon (DLR, Oberpfaffenhofen) in August 2001 as part of the Mediterranean Intensive Oxidant Study (MINOS). A summary of the major results of the MINOS campaign can be found in Lelieveld et al. (2002).

In the following section the $\mathrm{HCHO}$ instrument is described and characterized in detail, while Sect. 3 describes the observations made during MINOS. In Sect. 4 we present an intercomparison of the observations with predictions by a 3D chemical transport model. Section 5 includes sensitivity studies based on box model calculations with more detailed NMVOC chemistry. The findings of this study are discussed in Sect. 6 and summarized in the final section.

\section{Experimental}

A commercially available instrument (AERO Laser model AL 4021, Germany), modified for airborne operation, has been used for in-situ HCHO measurements. The instrument is based on the Hantzsch reagent method, initially used in a colorimetric technique by Nash (1953), following the design described in Kelly and Fortune (1994). In a first step, HCHO is stripped from a flow of $1 \mathrm{~L} / \mathrm{min}$ (STP) of ambient air into $0.1 \mathrm{~N} \mathrm{H}_{2} \mathrm{SO}_{4}\left(0.45 \mathrm{ml} \mathrm{min}^{-1}\right)$ in a stainless steel coil, temperature stabilized at $10^{\circ} \mathrm{C}$. The acidity of the stripping solution $(\mathrm{pH} \approx 1)$ maximises the solubility of HCHO, and minimises the dissolution of ambient $\mathrm{SO}_{2}$, a potential interferent of the detection process. In a second step, the $\mathrm{HCHO}$ in solution reacts with 2,4-pentanedione (acetylacetone) to form $\mathrm{C}_{6} \mathrm{H}_{8} \mathrm{O}_{2}$ and with ammoniumacetate to form $\mathrm{C}_{5} \mathrm{H}_{9} \mathrm{NO}$. Both products combine to form 3,5-diacetyl-1,4dihydrolutidine (DDL) in the so-called Hantzsch reaction.

The reaction sequence takes place in a temperature stabilized $\left(65^{\circ} \mathrm{C}\right)$ stainless steel reaction coil. The detection and quantification of DDL is accomplished via fluorescence spectroscopy with a photomultiplier tube (Hamamatsu model H957-01, Japan) at $510 \mathrm{~nm}$ after excitation at $400 \mathrm{~nm}$ by means of a Hg-lamp (BHK-Inc., USA). The instrument response time (10\%-90\%), determined from a step concentration change applied to the inlet, is approx. $180 \mathrm{~s}$, after a delay time of approx. $260 \mathrm{~s}$ caused by the stripping and reaction coils.

Similar instruments have been used previously for ground and ship-based (Weller et al., 2000) measurements of HCHO. In several $\mathrm{HCHO}$ measurement technique intercomparisons Hantzsch instruments were compared to Differential Optical Absorption Spectroscopy (DOAS) and Tunable Diode Laser Absorption Spectroscopy (TDLAS) measurements, showing good agreement (Macdonald et al., 1999; Cardenas et al., 2000). To operate the instrument on a jet aircraft, the pressure decrease of ambient air with increasing altitude has to be accounted for. This was done by means of a constant pressure inlet, that stabilised the inlet pressure of the $\mathrm{AL}$ 4021 to $1200 \mathrm{hPa}$ using two chemically inert Teflon membrane pumps (KNF Neuberger, model KN 828 KNDC, Germany) and a pressure control loop. Sampling of ambient air was accomplished via 1/4" PTFE tubing fed into a forward directed stainless steel inlet tube. The constant pressure inlet guarantees a pressure independent measurement between the boundary layer and the maximum ceiling of the Falcon $(13 \mathrm{~km}, \sim 150 \mathrm{hPa})$.

The in-field calibrations were performed with a $1 \mu \mathrm{M}$ HCHO liquid-phase standard solution (corresponding to a gas phase concentration of $10 \mathrm{ppbv}$ ) before and after each measurement flight to determine the sensitivity of the instrument. In addition an in-flight calibration was made during MINOS flight No. 9 on 17 August 2001. An extensive laboratory based comparison of the liquid phase calibration with gas phase calibrations based on a permeation device (KIN-TEK, model HRT, USA) demonstrated good agreement within the combined uncertainties of the liquid and gas-phase calibration standards $(10 \%)$. The instrument background was determined after each calibration by passing ambient air over a built-in Hopcalit $\left(60 \% \mathrm{MnO}_{2}\right.$, $40 \% \mathrm{CuO}$ ) scrubber to remove $\mathrm{HCHO}$. In addition, zero air 


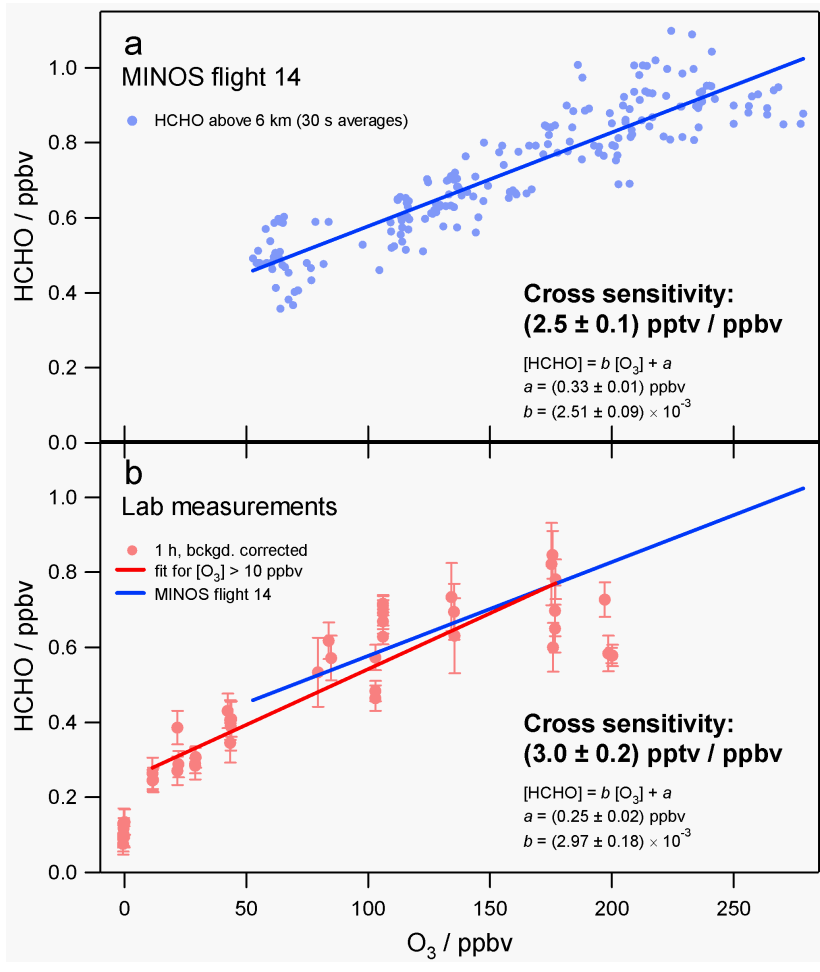

Fig. 1. Scatter plots of $\mathrm{HCHO}$ versus $\mathrm{O}_{3}$ for MINOS data from the lowermost stratosphere (a) and laboratory based experiments with hydrocarbon-free zero air (b).

measurements were performed on a regular basis during the measurement flights. The precision $(1.5 \%$ at $10 \mathrm{ppbv})$ and the detection limit (42 pptv) were determined from the reproducibility ( $1 \sigma$-standard deviation) of the instrument calibrations and in-flight zero measurements, respectively.

Contrary to HCHO measurement systems based on optical absorption spectroscopy, e.g. DOAS (Platt and Perner, 1980) or TDLAS (Harris et al., 1989; Fried et al.,1997; Wagner et al., 2001), the Hantzsch reaction is not free of interferences, caused by other atmospheric constituents in the gas phase. These may be caused by species that are transferred into solution and in addition form photosensitive products that fluoresce in the same wavelength region as DDL. Cross sensitivity studies in the literature mainly deal with the role of higher aldehydes and ketones in forming alternative pyridines that could exhibit similar fluorescence spectra, or the influence of dissolved amines, competing with the formation of acetylacetoamine (Dong and Dasgupta, 1987; Dasgupta et al., 1988; Kelly and Fortune, 1994). In general, the interfering species have a lower solubility than $\mathrm{HCHO}$ and rather low concentrations in the background atmosphere, promoting an interference-free measurement of HCHO. A further interfering process is the production of methane sulfonic acid from dissolved $\mathrm{SO}_{2}$, which is efficiently suppressed by the use of an acid stripping solution (Dong and Dasgupta, 1987).
Lower stratospheric measurements during the MINOS campaign indicated a significant increase of the instrument reading above the tropopause, pointing towards an ozone interference in the basic $\mathrm{HCHO}$ detection process or secondary $\mathrm{HCHO}$ formation in the inlet system. Figure 1a shows measurements obtained in the lowermost stratosphere during MINOS flight No. 14 on 22 August 2001. A significant positive correlation $(\mathrm{r}=0.91)$ between $\mathrm{HCHO}$ and $\mathrm{O}_{3}$ has been observed for $\mathrm{O}_{3}$ concentrations in excess of $100 \mathrm{ppbv}$. A least square regression fit yields a slope of $(2.5$ $\pm 0.1) \mathrm{pptv} / \mathrm{ppbv}$. To investigate the nature of this interference, laboratory studies were performed. Figure $1 \mathrm{~b}$ shows results from laboratory-based experiments with hydrocarbon free air produced by a catalytic conversion of $\mathrm{NMHC}$ to $\mathrm{CO}_{2}$ (Headline filters, model CAP60, Germany) followed by a cryogenic trap $(T<180 \mathrm{~K})$. Illumination of the purified zero air with UV light (ansyco GPT) provided variable $\mathrm{O}_{3}$ concentrations quantified by a UV absorption instrument (environment s.a., model O3-41M). Similar to the lower stratospheric observations a linear regression was observed, indicating a cross sensitivity of $(3.0 \pm 0.2) \mathrm{pptv} / \mathrm{ppbv}$, in good agreement with the slope of the stratospheric measurements. Based on these laboratory studies, it is rather unlikely that the observed interference is predominantly due to production of HCHO from residual hydrocarbons in ultra-clean zero air during the $\mathrm{O}_{3}$ production process (Macdonald et al., 1999) or secondary $\mathrm{HCHO}$ production from organic aerosols due to reactions with $\mathrm{O}_{3}$ on the inlet walls (Thomas et al., 2001). Instead, our results indicate a direct cross sensitivity of the Hantzsch reaction itself towards $\mathrm{O}_{3}$, although the detailed mechanism remains to be resolved. Note that extrapolation of the laboratory regression line to zero $\mathrm{O}_{3}$ concentrations provides a HCHO concentration of $(245 \pm 16)$ pptv, significantly higher than observations $(106 \pm 60)$ pptv, most probably indicating incomplete removal of hydrocarbons in the cold trap, and some contribution of secondary $\mathrm{HCHO}$ formation during the $\mathrm{O}_{3}$ production process in the laboratory studies. For the following discussion, all HCHO measurements have been corrected for the observed $\mathrm{O}_{3}$ interference using a cross sensitivity of $2.5 \mathrm{pptv} / \mathrm{ppbv}$. In addition, a further correction was made to account for an observed temperature dependency of the instrument of $1.6 \% /{ }^{\circ} \mathrm{C}$. Including all these measures, we estimate the total uncertainty of the $\mathrm{HCHO}$ data to be of the order of $30 \%$ at a mixing ratio of 300 pptv.

\section{Observations}

A detailed discussion of the objectives and the major findings of the MINOS campaign can be found in Lelieveld et al. (2002). Fourteen measurement flights were performed in the marine boundary layer and the free troposphere over the Mediterranean basin. The majority (11) of the flights took place over the eastern Mediterranean Sea near Crete, 
Table 1. Mean, median, and $1 \sigma$ standard deviation (STD) for all flights and flights No. 2 and 8 separately as a function of $1 \mathrm{~km}$ altitude bins

\begin{tabular}{cccccccccc}
\hline & \multicolumn{3}{c}{ All flights } & \multicolumn{3}{c}{ Flight No. 2 } & \multicolumn{3}{c}{ Flight No. 8 } \\
Altitude & Mean & Median & STD & Mean & Median & STD & Mean & Median & STD \\
\hline $0-1$ & 1306 & 1107 & 522 & 1506 & 1468 & 220 & 1000 & 978 & 103 \\
$1-2$ & 1177 & 1133 & 485 & 1292 & 1274 & 250 & 976 & 965 & 166 \\
$2-3$ & 720 & 666 & 331 & 1059 & 1061 & 252 & 701 & 718 & 253 \\
$3-4$ & 483 & 499 & 233 & 678 & 622 & 161 & 394 & 423 & 134 \\
$4-5$ & 377 & 389 & 204 & 679 & 624 & 207 & 242 & 243 & 96 \\
$5-6$ & 251 & 238 & 147 & 617 & 646 & 118 & 293 & 328 & 110 \\
$6-7$ & 280 & 260 & 135 & 703 & 730 & 102 & 214 & 161 & 117 \\
$7-8$ & 347 & 328 & 135 & 768 & 652 & 212 & 281 & 311 & 52 \\
$8-9$ & 315 & 315 & 157 & 782 & 788 & 113 & 270 & 282 & 76 \\
$9-10$ & 355 & 399 & 132 & 840 & 806 & 97 & 280 & 318 & 80 \\
$10-11$ & 409 & 413 & 195 & 1062 & 1069 & 65 & 114 & 126 & 85 \\
$11-12$ & 366 & 364 & 144 & 1276 & 1333 & 181 & 218 & 216 & 61 \\
\hline
\end{tabular}

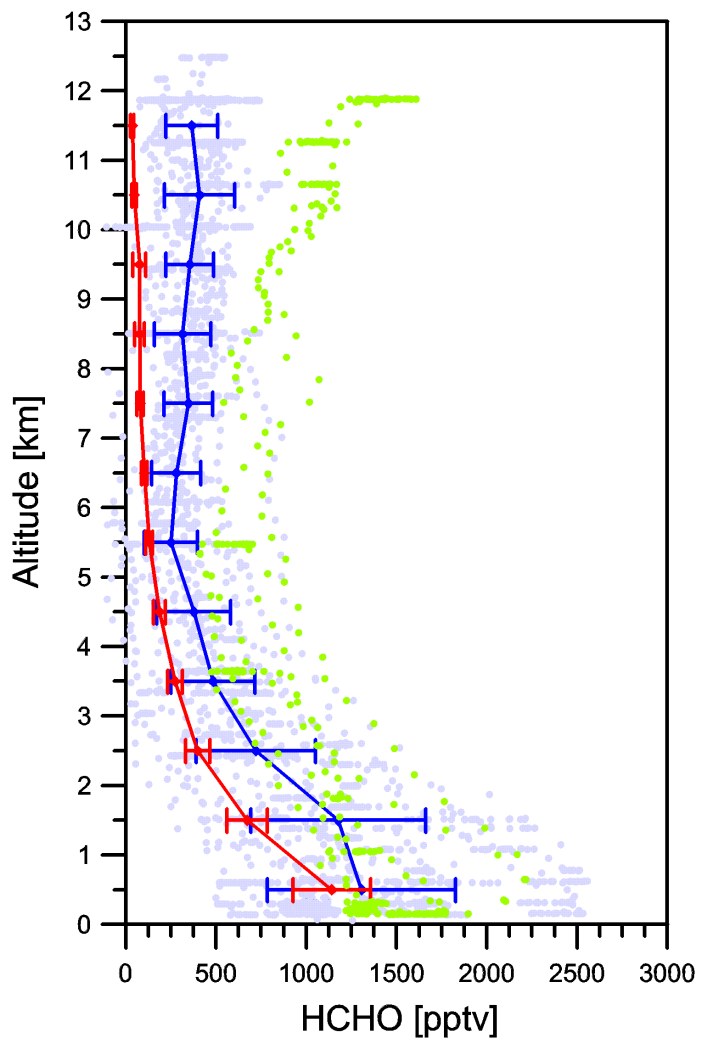

Fig. 2. Altitude profile of measured (blue: individual measurements; dark blue: means and $1 \sigma$-standard deviations over $1 \mathrm{~km}$ altitude bins) and modelled HCHO mixing ratios (red). Data measured during Flight No. 2 are plotted in green.

with Heraklion serving as the base for the DLR Falcon aircraft. Formaldehyde was measured during twelve flights performed between 1 August 2001 and 22 August 2001. In Fig. 2 the mean profile ( $\pm 1 \sigma$ standard deviation) is plotted as a function of altitude. The individual measurements (light blue points in Fig. 2) have been binned into $1 \mathrm{~km}$ altitude intervals $(0-1 \mathrm{~km}$, etc) and averaged. The mean, median and standard deviations for the individual altitude bins are listed in Table 1. In general, $\mathrm{HCHO}$ concentrations were highest in the marine boundary layer $(\sim 1500 \mathrm{pptv})$ and decreased with increasing altitude. Lowest concentrations were observed in the middle troposphere at $5-7 \mathrm{~km}$, at mean mixing ratios of the order of 250 pptv.

In the upper troposphere $\mathrm{HCHO}$ slightly increased to mean values in excess of $350 \mathrm{pptv}$ at $10-12 \mathrm{~km}$. In particular in the upper troposphere, the mean mixing ratio of $\mathrm{HCHO}$ showed a dependency on the airmass origin deduced from backward trajectories (Traub et al., 2003). The lowest mean concentrations of HCHO of the order of 110 pptv at $10-11 \mathrm{~km}$ (Table 1) were observed during flight No. 8 on 16 August 2001. Backward trajectories indicated an airmass origin over the west Atlantic for this particular flight. The highest mixing ratio in excess of $1 \mathrm{ppbv}$ (Table 1 and green data points in Fig. 2) were observed during flight No. 2 (03 August 2001) in the outflow of the Indian monsoon convection probed above $8 \mathrm{~km}$ altitude (Lelieveld et al., 2002; Traub et al., 2003; Scheeren et al., 2003).

The average concentration of $\mathrm{HCHO}$ in the marine boundary layer $(0-1 \mathrm{~km})$ is at least a factor of three higher than measurements in the remote areas of the Atlantic, Pacific or Indian Ocean (Zafirou et al., 1980; Lowe and Schmidt, 1983; Arlander et al., 1990; Heikes, 1992; Harris et al., 1992; Zhou et al., 1996; Mackay et al., 1996; Jacob et al., 1996; Ayers et al., 1997; Jaeglé et al., 2000; Weller et al., 2000; Wagner et al., 2001) and comparable to continental background conditions (Harder et al., 1997; Fischer et al., 2003). This is mainly due to advection of pollution from eastern and western Europe at altitudes below $4 \mathrm{~km}$ (Traub et al., 2003). In particular in the outflow of eastern Europe a strong contribution from biomass burning has been observed (Traub et 
Table 2. Mean, median, $1 \sigma$ standard deviation (STD), range (all in pptv) and number of data points for altitude bins of $1 \mathrm{~km}$ each obtained from observations (all flights except No. 2) and model results. Values at or below the detection limit are labeled DL

\begin{tabular}{cccccccccc}
\hline \multicolumn{4}{c}{ Observations } & \multicolumn{7}{c}{ MATCH model results } \\
\hline Altitude & Mean & Median & STD & Range & Mean & Median & STD & Range & Number \\
\hline $0-1$ & 1306 & 1107 & 522 & $498-2556$ & 1141 & 1131 & 215 & $574-1670$ & 605 \\
$1-2$ & 1177 & 11336 & 485 & $250-2409$ & 672 & 660 & 112 & $364-1056$ & 311 \\
$2-3$ & 720 & 666 & 331 & $51-1517$ & 399 & 404 & 68 & $221-589$ & 236 \\
$3-4$ & 483 & 499 & 233 & DL-1260 & 273 & 280 & 41 & $173-435$ & 260 \\
$4-5$ & 377 & 389 & 204 & DL-905 & 187 & 181 & 33 & $118-263$ & 113 \\
$5-6$ & 251 & 238 & 147 & DL-877 & 130 & 130 & 19 & $94-192$ & 277 \\
$6-7$ & 280 & 260 & 135 & DL-823 & 103 & 104 & 15 & $77-164$ & 128 \\
$7-8$ & 347 & 328 & 135 & DL-792 & 80 & 75 & 17 & $60-162$ & 154 \\
$8-9$ & 315 & 315 & 157 & DL-741 & 76 & 67 & 27 & $48-161$ & 211 \\
$9-10$ & 355 & 399 & 132 & $49-596$ & 76 & 60 & 36 & $37-150$ & 178 \\
$10-11$ & 409 & 413 & 195 & DL-852 & 47 & 41 & 12 & $28-87$ & 231 \\
$11-12$ & 366 & 364 & 144 & $39-741$ & 36 & 38 & 9 & $22-59$ & 474 \\
\hline
\end{tabular}

al., 2003). In the middle and upper troposphere mean concentrations over the Mediterranean were on average a factor of two higher than those observed over the tropical Pacific (Heikes et al., 2001) and the North and South Atlantic (Arlander et al., 1995; Jaeglé et al., 2000). Note that these previous HCHO measurements were performed during different seasons and at different locations around the globe, which limits their comparability towards the MINOS findings. Good agreement is found with $\mathrm{HCHO}$ observations in the middle troposphere during the NARE 97 campaign over the North Atlantic in September 1997 (Fried et al., 2002). Fried et al. (2002) report average concentrations of $265 \mathrm{pptv}$ at 4-8 km, comparable to MINOS (Table 1), in particular for flight No. 8.

Observations above $4 \mathrm{~km}$ during MINOS flight No. 2 yield $\mathrm{HCHO}$ mixing ratios that are approximately a factor of 10 higher than observed in several previous missions (Arlander et al., 1995; Jacob et al., 1996; Jaeglé et al., 2000; Heikes et al., 2001; Fried et al., 2002). They are comparable, however, to airborne observations of HCHO during the Southern Oxidants Study in the continental free troposphere over the south-eastern United States in summer 1995 (Lee et al., 1998).

\section{Comparison to 3D-model results}

Figure 2 includes an average profile deduced from model simulations (red curve), performed with the 3D chemistry transport model MATCH-MPIC (Model of Atmospheric Transport and Chemistry - Max Planck Institute for Chemistry version) (Lawrence et al., 1999; von Kuhlmann, 2001; von Kuhlmann et al., 2003a). The model is driven by meteorological data from the NCEP weather center and includes an extensive non-methane hydrocarbon oxidation mechanism described in detail by von Kuhlmann (2001). The model resolution is $2.8^{\circ}$ in the horizontal and includes 42 levels in the vertical up to about $2 \mathrm{hPa}$. During MINOS the model was used to provide chemical weather forecasts to assist the flight planning of the Falcon (Lawrence et al., 2003). The average profile (in $1 \mathrm{~km}$ altitude bins) was calculated from "virtual flights" through the model domain, following the aircraft trajectories of the Falcon missions. Figure 2 shows the average profile and the $1 \sigma$-standard deviation, while Table 2 contains detailed information on means, medians, standard deviations and ranges for the individual altitude bins, compared to the corresponding observational data.

Figure 3 shows the absolute ( $\triangle \mathrm{HCHO}$ (obs-model) in pptv, Fig. 3a) and relative $\left(\mathrm{HCHO}^{\text {obs }} / \mathrm{HCHO}^{\text {model }}\right.$, Fig. 3b) deviations between observations and model simulations for three altitude regimes $(0-4 \mathrm{~km}, 4-8 \mathrm{~km}, 8-12 \mathrm{~km})$. The relative difference of $\mathrm{HCHO}$ in the lower two layers is approx. $200 \mathrm{pptv}$ (less than a factor 3), increasing to 300 400 pptv (factor of 8) at higher altitudes.

To investigate the causes of the large discrepancy between observations and model results, Fig. 4 shows average profiles, observations and model outputs, for a number of measured trace gases. While model and measurements largely agree for $\mathrm{O}_{3}, \mathrm{CO}$, and $\mathrm{NO}_{\mathrm{y}}$, large deviations are obtained for $\mathrm{NO}, \mathrm{PAN}, \mathrm{CH}_{3} \mathrm{OH}$, and acetone. In particular the acetone concentration is strongly underestimated by $\mathrm{MATCH}$ throughout the troposphere (factor of 10). As pointed out by Crawford et al. (1999), acetone photolysis has a strong influence on the $\mathrm{HCHO}$ budget in the upper troposphere, so that a model underestimation of acetone might result in an underestimation of $\mathrm{HCHO}$ as well.

Significant positive correlations were observed between measured $\mathrm{HCHO}$ and acetone and $\mathrm{CH}_{3} \mathrm{OH}$, respectively, as well as between $\mathrm{HCHO}$ and $\mathrm{CO}$, a tracer for combustion 


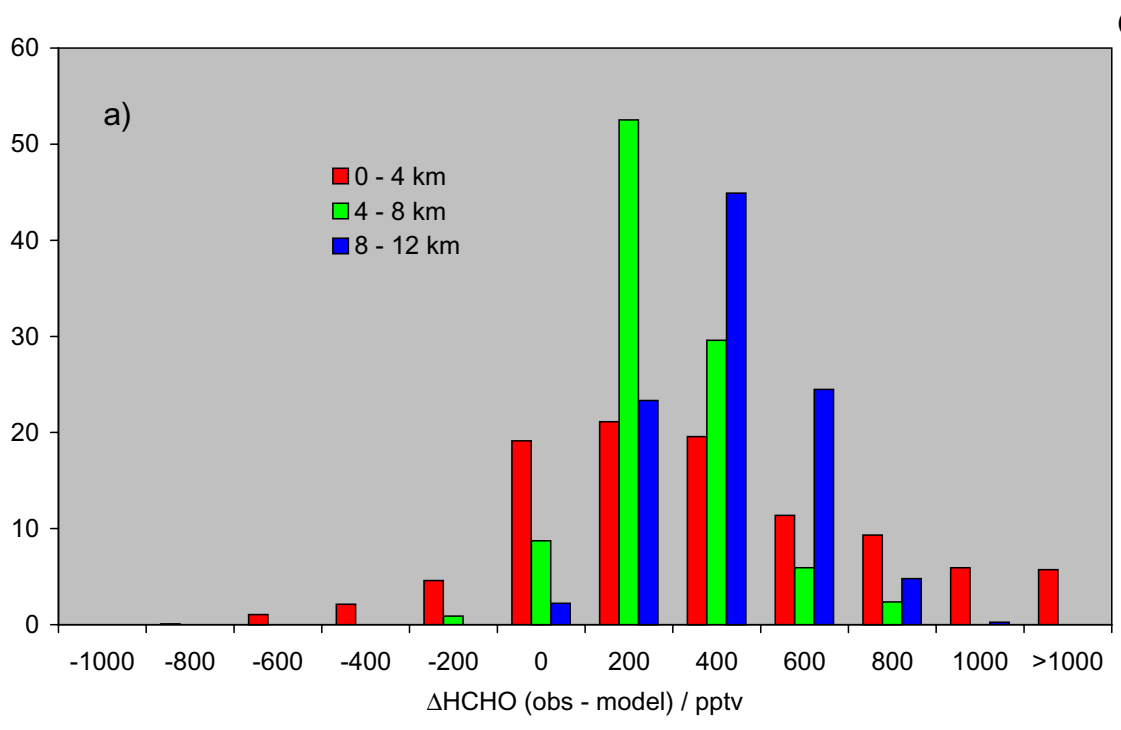

(a)

(b)

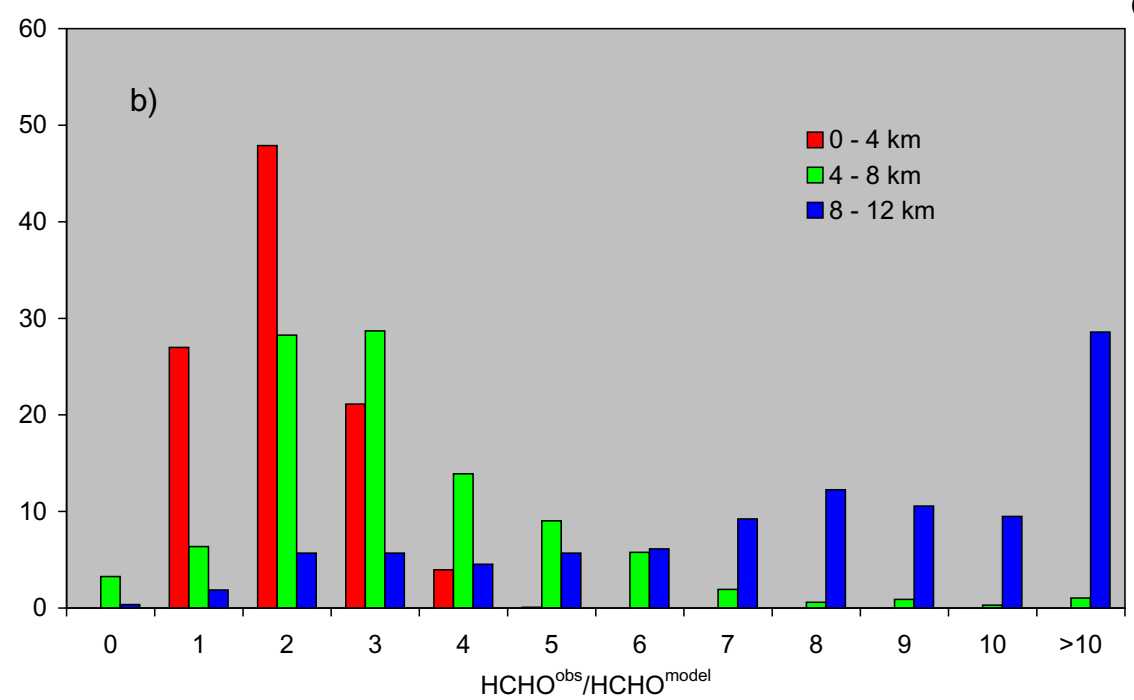

Fig. 3. Histograms (\%) of the difference (a) and the ratio (b) between measured and modelled $\mathrm{HCHO}$ mixing ratios in three different altitude bins (red: $0-4 \mathrm{~km}$; green: $4-8 \mathrm{~km}$; blue: $8-12 \mathrm{~km}$ ).

emissions (Fig. 5). This could indicate that a significant $\mathrm{HCHO}$ precursor, either acetone or some other species, coemitted with $\mathrm{CO}$, is not, or not at sufficiently high concentration, represented in MATCH. To check whether the missing acetone in the model can account for the too small HCHO, box model calculations were performed.

\section{Sensitivity studies using box model calculations}

A time dependent photochemical box model was used to study the role of acetone on the HCHO budget of the upper troposphere. The box model has been described in detail by Brühl et al. (2000). The model, which includes detailed VOC chemistry scheme, was initialised with average con- centrations for the upper troposphere observed during the MINOS campaign (200 pptv $\mathrm{NO}_{\mathrm{x}}, 100 \mathrm{pptv}$ PAN, $85 \mathrm{ppbv}$ $\mathrm{CO}$, and $100 \mathrm{ppbv} \mathrm{O}_{3}$ ). Sensitivity runs with varied concentrations of acetone and $\mathrm{CH}_{3} \mathrm{OH}$ were made and compared to a base run $\left(\mathrm{CH}_{4}\right.$ chemistry only). In general, the $\mathrm{HCHO}$ concentration significantly increased with increasing concentrations of acetone. After a small decrease in the first $48 \mathrm{~h}$ the delta $\mathrm{HCHO}$ is almost constant for the following 15-20 days, indicating significant secondary $\mathrm{HCHO}$ formation in air masses remote from the source region. The relative increase of HCHO after 20 days of model simulation is of the order of $28 \mathrm{pptv} / \mathrm{ppbv}$ for acetone. This result strongly depends on the PAN and $\mathrm{NO}_{\mathrm{x}}$ background mixing ratios. The effect of $\mathrm{CH}_{3} \mathrm{OH}$ is largest during the first day of the model run (11 pptv/ppbv) and decreases strongly to $\approx 1 \mathrm{pptv} / \mathrm{ppbv}$ 


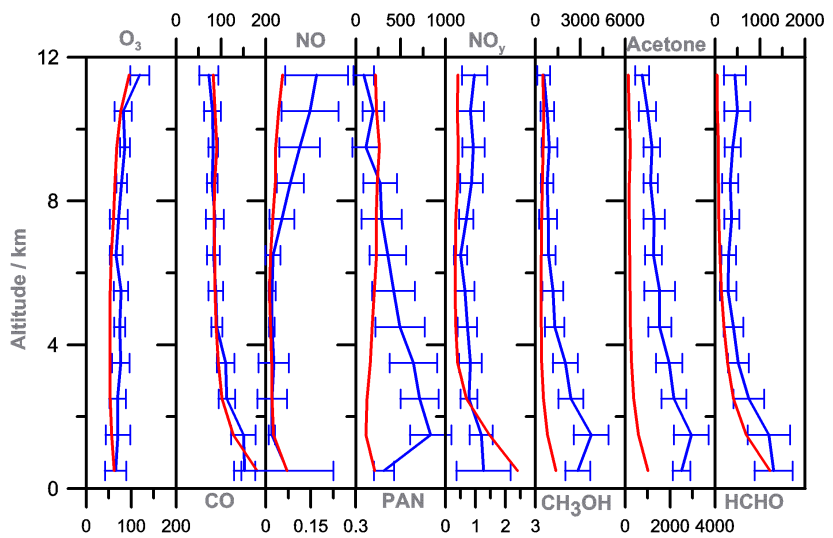

Fig. 4. Altitude profiles of mean observed (blue) and modelled (red) mixing ratios in $1 \mathrm{~km}$ altitude bins for various trace gases measured during MINOS. All mixing ratios are given in pptv, except $\mathrm{CO}, \mathrm{NO}_{\mathrm{y}}$ and $\mathrm{O}_{3}$ (ppbv).

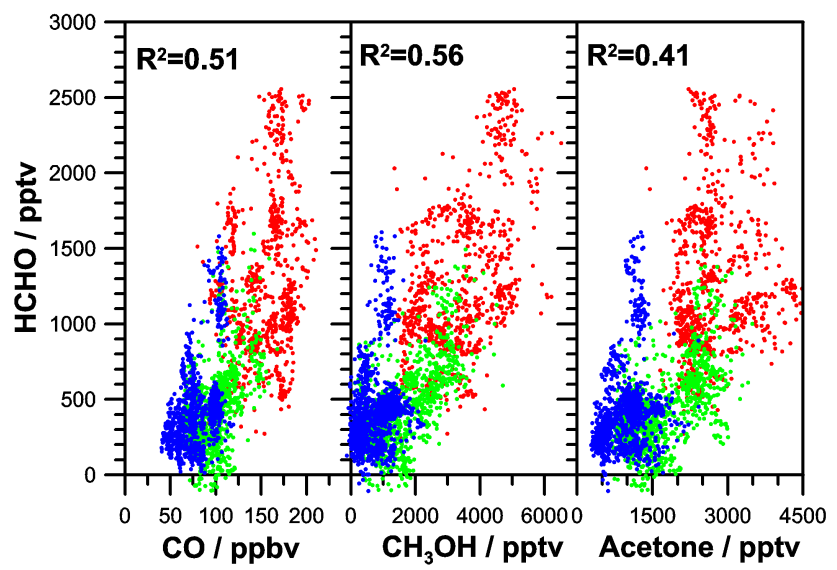

Fig. 5. Scatter plots of $\mathrm{HCHO}$ versus $\mathrm{CO}, \mathrm{CH}_{3} \mathrm{OH}$ and acetone, respectively. The colour code refers to different altitude intervals (red: 0-4 km; green: 4-8 km; blue: $8-12 \mathrm{~km}$ ).

after 20 days, reflecting the shorter photochemical lifetime of $\mathrm{CH}_{3} \mathrm{OH}$ compared to acetone in the upper troposphere. Based on this study it may be expected that the 3D-model $\mathrm{HCHO}$ would increase by $\sim 30 \mathrm{pptv}$, to a value of approx. 70 pptv, after including 1 ppbv of additional acetone. This increase is higher than that obtained by Singh et al. (2000) who indicated an acetone sensitivity of 10-15 pptv/ppbv. These box model sensitivity studies clearly indicate that the underestimation of acetone, presumably related to an emission deficit, cannot be the sole cause of the strong underestimation of HCHO by the MATCH model. To close the budget an equivalent of at least $10 \mathrm{ppbv}$ of an acetone-like HCHO precursor would have to be included. Note that the HCHO mixing ratio also depends on the $\mathrm{NO}$ mixing ratio in the upper troposphere, since the reaction of $\mathrm{NO}$ with $\mathrm{CH}_{3} \mathrm{O}_{2}$ governs the rate of $\mathrm{HCHO}$ formation. Since NO is also underesti- mated in $\mathrm{MATCH}$, the $\mathrm{HCHO}$ enhancement in the box model runs is partly due to enhanced $\mathrm{NO}$ in the upper troposphere.

\section{Discussion}

Recent studies of HCHO in the middle and upper free troposphere indicate that state-of-the-art model predictions are generally consistently lower than observations. Table $3 \mathrm{com}-$ pares observations and model results during the MINOS campaign (August 2001, Mediterranean basin, model results from 3D CTM with increased acetone concentration) with results from NARE-97 (September 1997, North Atlantic Ocean, model results from box model runs constrained by observations) (Frost et al., 2002), SONEX (OctoberNovember 1997, North Atlantic Ocean, model results from box model runs constrained by observations, acetone deduced from CO observations) (Jaeglé et al., 2000), PEMTropics B (March-April 1999, tropical central Pacific, model results from box model runs constrained by observations) (Heikes et al., 2001) and TROPOZ II (January 1991, tropical Atlantic, model results from box model runs constrained by observations, acetone not included). Although different measurement techniques, model types and chemistry schemes have been used, Table 3 confirms the tendency of the models to underestimate the concentration of upper tropospheric $\mathrm{HCHO}$ by a factor of $1.5-5$. The observationmodel discrepancies are largest for modestly polluted areas (MINOS, NARE, SONEX). Smallest differences between observations and models are achieved for the tropical Pacific (PEM-Tropics B) and Atlantic (TROPOZ-II) areas, respectively, where trace gas and aerosol number concentrations are typically factors of 2 to 10 smaller than over the Mediterranean (Lelieveld et al., 2002).

Fried et al. (2003) report observations of HCHO obtained during a series of TOPSE measurement flights between February and May 2000. They compared in-situ observations of HCHO with box model results and generally found good agreement for background conditions, while data affected by recent pollution showed large observationmodel deviations. In addition, they found that for background conditions at very low temperatures (starting around $-45^{\circ} \mathrm{C}$ ), significant and persistent observation-model differences were found during the early deployments at low light levels at high latitudes in the $6-8 \mathrm{~km}$ altitude range, sometimes with measured $\mathrm{HCHO}$ exceeding modelled mixing ratios by nearly $400 \mathrm{pptv}$ (median difference $132 \mathrm{pptv}$ or $83 \%$ ).

Taking into account that different measurement techniques have been used for the observations listed in Table 3, it seems unlikely that the reported measurement-model discrepancies are due to instrument artefacts caused by interfering species. Nevertheless, one has to consider that all techniques applied so far require the transfer of ambient air into the $\mathrm{HCHO}$ sensor via an inlet system. Laboratory based studies by Thomas et al. (2001) report the formation of HCHO under 
Table 3. HCHO observation/model comparisons in the free troposphere (Mixing ratios and differences of mixing ratios are given in pptv)

\begin{tabular}{cccccc}
\hline & MINOS $^{1}$ & NARE-97 $^{2}$ & SONEX $^{3}$ & PEM-T B $^{4}$ & TROPOZ-II $^{5}$ \\
\hline$[$ HCHO $]$ & $340 \pm 150$ & $230 \pm 150$ & $0-270$ & 55 & 110 \\
Obs/Model & $\sim 5$ & $1.84 \pm 0.34$ & $\sim 2.1$ & 1.4 & 1.5 \\
Obs - Model & $\sim 250$ & $\sim 140$ & & 15 & \\
\hline
\end{tabular}

1 this study, data above $6 \mathrm{~km}$ except from flight 2, model result from MATCH including 1 ppbv of acetone

${ }^{2}$ (Frost et al., 2002), data between $4-8 \mathrm{~km}$

3 (Jaeglé et al., 2000), data between $8-12 \mathrm{~km}$

4 (Heikes et al., 2001), data above $8 \mathrm{~km}$

5 (Arlander et al., 1995), data from the tropics (20S-20N), between 6 and $10 \mathrm{~km}$

dry conditions in a reaction of ozone with terminal alkenes serving as a proxy for atmospheric organic aerosols, indicating that in principle aerosol contaminated inlet lines could be responsible for artificial HCHO formation. Although a dependency of $\mathrm{HCHO}$ on $\mathrm{O}_{3}$ concentrations was observed during MINOS, laboratory studies indicated that this was most likely not due to secondary $\mathrm{HCHO}$ formation in the inlet system (see Sect. 2). This is in line with observations by Wert et al. (2002), who did not find sampling artefacts in an extensive evaluation of an inlet system similar to the one used for the HCHO measurements in the present study.

Although an instrument artefact cannot be completely ruled out, it is more likely that the higher HCHO concentrations observed in this study, as well as those reported in the literature, point to a missing HCHO source in the middle and upper troposphere. Recent studies (Ayers et al., 1997; Weller et al., 2000; Elrod et al., 2001; Fried et al., 2003) investigated whether direct production of $\mathrm{HCHO}$ in the reaction of $\mathrm{CH}_{3} \mathrm{O}_{2}$ with $\mathrm{HO}_{2}$, circumventing the production of $\mathrm{CH}_{3} \mathrm{OOH}$, may enhance the production of formaldehyde. Relying on recent kinetic studies of the temperature dependency of the branching ratio between direct $\mathrm{HCHO}$ versus $\mathrm{CH}_{3} \mathrm{OOH}$ formation for this reaction (Elrod et al., 2001), Fried et al. (2003) came to the conclusion that this process is not sufficiently important to explain the measurementmodel discrepancies. Based on sensitivity studies, they also excluded reaction of $\mathrm{CH}_{4}$ with $\mathrm{Cl}$ or errors in the $\mathrm{HCHO}$ photolysis rate at low temperatures as being responsible for the model underestimation of $\mathrm{HCHO}$.

The observation of a positive correlation among $\mathrm{HCHO}$ and $\mathrm{CH}_{3} \mathrm{OH}$, which was also observed in this study, stimulated Jaeglé et al. (2000) to speculate about the heterogeneous conversion of methanol to $\mathrm{HCHO}$ on cirrus clouds, although recent laboratory experiments by Iraci et al. (2002) did not find evidence for such a process. A further potential HCHO production mechanism could be photochemical degradation of unmeasured partially oxidized hydrocarbons. Frost et al. (2002) concluded that additional VOCs with a total reactivity equivalent to $1.3 \mathrm{ppbv} \mathrm{CH}_{3} \mathrm{OOH}, 12 \mathrm{ppbv}$ acetone, or 11 ppbv $\mathrm{CH}_{3} \mathrm{OH}$ would be needed to account for a measured-modelled HCHO difference of 184 pptv.

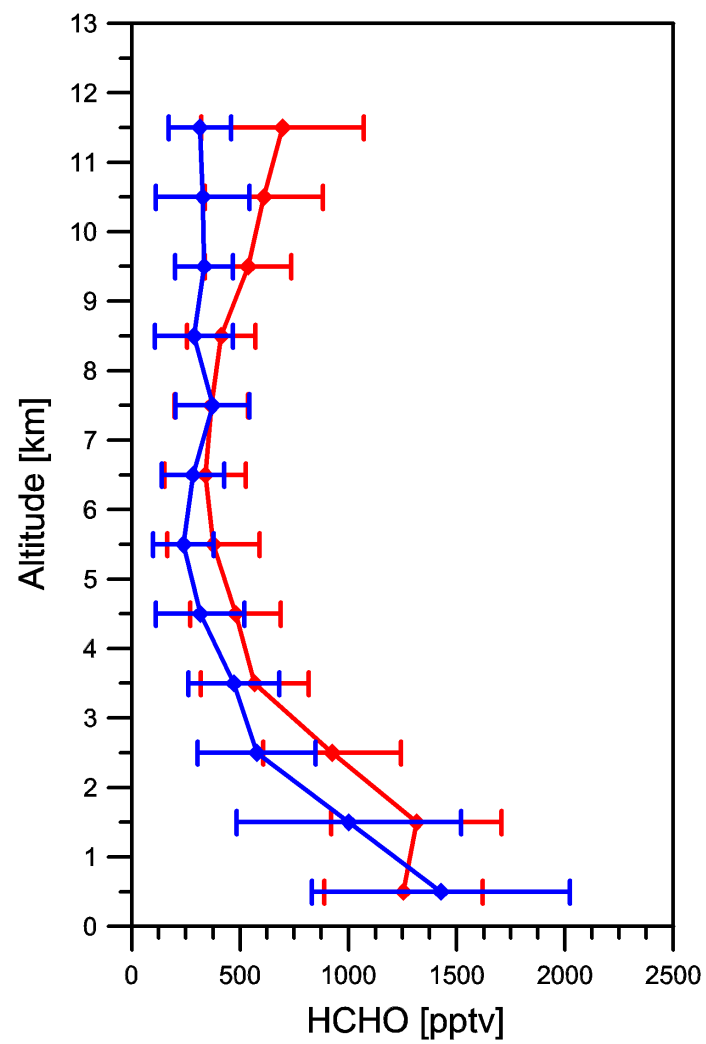

Fig. 6. Altitude profiles of mean and $1 \sigma$-standard deviation of $\mathrm{HCHO}$ for different airmass origins in the upper troposphere. Red data represent observations from MINOS flights No. 1-5 performed under the influence of the Indian summer monsoon, while the blue data are from flights No. 6-14 (North Atlantic/North American airmass origin).

Further indirect evidence for the role of additional organic precursors comes from this study. As discussed in Sect. 3 the $\mathrm{HCHO}$ level in the upper troposphere is strongly dependent on the airmass origin. While the MATCH model results predict low and rather constant values in the upper troposphere, Fig. 6 shows that average HCHO mixing ratios in airmasses affected by the Indian summer monsoon (red 
curve, Flights No. 1-5) are significantly higher than in airmasses from the North Atlantic/North American area (blue curve, Flights No. 6-14) (Traub et al., 2003; Scheeren et al., 2003). The influence of the monsoon outflow is strongest at the highest altitudes, which is reflected in the increasing $\mathrm{HCHO}$ levels above $7 \mathrm{~km}$. In an accompanying paper, Scheeren et al. (2003) show that these airmasses are rich in combustion products of biofuel use. In contrast to this observation, the North Atlantic/North American HCHO profile is a nearly constant above $5 \mathrm{~km}$ at levels comparable to those observed over the North Atlantic during NARE-97 (Fried et al., 2002; Frost et al., 2002). This could indicate that additional, long-lived VOCs associated with biomass combustion are at least partially responsible for the obtained observationmodel discrepancies for $\mathrm{HCHO}$.

\section{Summary and conclusions}

Airborne formaldehyde measurements based on the Hantzsch reaction technique were performed over the eastern Mediterranean Sea during the MINOS campaign in August 2001. Measured concentrations in the marine boundary layer of the order of $1.3 \mathrm{ppbv}$ are relatively well simulated by a chemistry-transport model (MATCH). At higher altitudes (above $6 \mathrm{~km}$ ) $\mathrm{HCHO}$ levels decreased to $0.34 \mathrm{ppbv}$, though much higher than predicted by the model $(\sim 0.05 \mathrm{ppbv})$. In general observed $\mathrm{HCHO}$ levels in the upper troposphere were dependent on the airmass origin. Vertical profiles affected by the Indian summer monsoon show minimum concentrations of approx. $300 \mathrm{pptv}$ at $6-7 \mathrm{~km}$, increasing to more than $600 \mathrm{pptv}$ above $11 \mathrm{~km}$, the altitude with the maximum observed monsoon influence. The HCHO profile for airmasses with a North Atlantic/North American origin show nearly constant values with altitude of the order of $280 \mathrm{pptv}$ above $5 \mathrm{~km}$, comparable to those observed over the North Atlantic during NARE-97 (Fried et al., 2002; Frost et al., 2002). Sensitivity studies indicate that the measurement-model disagreement cannot be resolved based on known chemistry and emissions. In particular the observed dependency of $\mathrm{HCHO}$ on airmass origin might indicate that unknown, relatively long-lived NMVOCs or their reaction intermediates - associated with biomass burning in South Asia are at least partially responsible for the HCHO observation-model discrepancies. To resolve this issue additional field and laboratory studies are needed.

Acknowledgement. We gratefully acknowledge the excellent collaboration with the pilots and technicians of the DLR Falcon. Additionally, we like to thank P. Stier and M. Schulz for additional in-field chemical weather forecasts, which proved to be very helpful in day to day flight planning.

\section{References}

Arlander, D. W., Cronn, D. R., Farmer, J. C., Menzias, F. A., and Westberg, H. H.: Gaseous oxygenated hydrocarbons in the remote marine troposphere, J. Geophys. Res., 95, 16391-16403, 1990.

Arlander, D. W., Brüning, D., Schmidt, U., and Ehhalt, D. H.: The tropospheric distribution of formaldehyde during TROPOZ II, J. Atmos. Chem., 22, 251-268, 1995.

Ayers, G. P., Gillett, R. W., Granek, H., de Serves, C., and Cox, R. A.: Formaldehyde production in clean marine air, Geophys. Res. Lett., 24, 401-404, 1997.

Brasseur, G. P., Hauglustaine, D. A., and Walters, S.: Chemical compounds in the remote Pacific troposphere: Comparison between MLOPEX measurements and chemical transport model calculations, J. Geophys. Res., 101, 14 795-14 813, 1996.

Brühl, C., Pöschl, U., Crutzen, P. J., and Steil, B.: Acetone and PAN in the upper troposphere: Impact on ozone production from aircraft emissions, Atmos. Environm., 34, 3931-3938, 2000.

Cardenas, L. M., Brassington, D. J., Allan, B. J., Coe, H., Alicke, B., Platt, U., Wilson, K. M., Plane, J. M., and Penkett, S. A.: Intercomparison of formaldehyde measurements in clean and polluted atmospheres, J. Atmos. Chem., 37, 53-80, 2000.

Carlier, P., Hannachi, H., and Mouvier, G.: The chemistry of carbonyl compounds in the atmosphere: A review, Atmos. Environm., 20, 2079-2099, 1986.

Crawford, J., Davis, D., Olson, J., Chen, G., Liu, S., Gregory, G., Sandholm, S., Heikes, B., Singh, H., and Blake, D.: Assessment of upper tropospheric $\mathrm{HO}_{\mathrm{x}}$ sources over the tropical Pacific based on NASA GTE/PEM data: Net effect on $\mathrm{HO}_{\mathrm{x}}$ and other photochemical parameters, J. Geophys. Res., 104, 16255-16273, 1999.

Dasgupta, P. K., Dong, S., Hwang, H., Yang, H.-C., and Genfa, Z.: Continuous liquid-phase fluorometry coupled to a diffusion scrubber for the real-time determination of atmospheric formaldehyde, hydrogen peroxide and sulfur dioxide, Atmos. Environm., 22, 949-963, 1988.

de Serves, C.: Gas phase formaldehyde and peroxide measurements in the Arctic atmosphere, J. Geophys. Res., 99, 25 391-25398, 1994.

Dong, S., and Dasgupta, P. K.: Fast fluorometric flow injection analysis of formaldehyde in atmospheric water, Environ. Sci. Techn., 21, 581-588, 1987.

Elrod, M. J., Ranschaert, D. L., and Schneider, N. J.: Direct kinetic study of the temperature dependence of the $\mathrm{CH}_{2} \mathrm{O}$ branching channel for the $\mathrm{CH}_{3} \mathrm{O}_{2}+\mathrm{HO}_{2}$ reaction, Int. J. Chem. Kinet., 33, 363-376, 2001.

Fischer, H., Kormann, R., Klüpfel, T., Gurk, Ch., Königstedt, R., Parchatka, U., Mühle, J., Rhee, T. S., Brenninkmeijer, C. A. M., Bonasoni, P., and Stohl, A.: Ozone production and trace gas correlations during the June 2000 MINATROC intensive measurement campaign at Mt. Cimone, Atmos. Chem. Phys., 3, 725-738, 2002.

Fried, A., Sewell, S., Henry, B., Wert, B. P., Gilpin, T., and Drummond, J. R.: Tunable diode laser absorption spectrometer for ground-based measurements of formaldehyde, J. Geophys. Res., 102, 6253-6266, 1997.

Fried, A., Lee, Y.-N., Frost, G., Wert, B., Henry, B., Drummond, J., Hübler, G., and Jobson, T.: Airborne $\mathrm{CH}_{2} \mathrm{O}$ measurements over the North Atlantic during the 1997 NARE campaign: In- 
strument comparisons and distributions, J. Geophys. Res., 107, D4, 10.1029/2000JD000260, 2002.

Fried, A., Wang, Y., Cantrell, C., Wert, B., Walega, J., Ridley, B., Atlas, E., Shetter, R., Lefer, B., Coffey, M.T., Hannigan, J., Blake, D., Blake, N., Meinardi, S., Talbot, B., Dibb, J. Scheuer, E., Wingenter, O., Snow, J., Heikes, B., and Ehhalt, D.: Tunable diode laser measurements of formaldehyde during the TOPSE 2000 study: Distributions, trends and model comparisons, J. Geophys. Res., 108, D4, 9365, doi: 10.1029/2002JD002208, 2003.

Frost, G. J., Fried, A., Lee, Y.-N., Wert, B., Henry, B., Drummond, J. R., Evans, M. J., Fehsenfeld, F. C., Goldan, P. D., Holloway, J. S., Hübler, G., Jakoubek, R., Jobson, B. T., Knapp, K., Kuster, W. C., Roberts, J., Rudolph, J., Ryerson, T. B., Stohl, A., Stroud, C., Sueper, D. T., Trainer, M., and Williams, J.: Comparison of box model calculations and measurements of formaldehyde from the 1997 North Atlantic Regional Experiment, J. Geophys. Res., 107, D8, 10.1029/2001JD000896, 2002.

Harder, J. W., Fried, A., Sewell, S., and Henry, B.: Comparison of tunable diode laser and lon-path ultraviolet/visible spectroscopic measurements of ambient formaldehyde concentrations during the 1993 OH Photochemistry Experiment, J. Geophy. Res., 102, 6267-6282, 1997.

Harris, G. W., Mackay, G. I., Iguchi, T., Mayne, L. K., and Schiff, H. I.: Measurements of formaldehyde in the troposphere by tunable diode laser absorption spectroscopy, J. Atmos. Chem., 8, 119-137, 1989.

Harris, G. W., Klemp, D., Zenker, T., Burrows, J. P., and Mathieu, B.: Tunable diode laser measurements of trace gases during the 1988 Polarstern cruise and intercomparison with other methods, J. Atmos. Chem., 15, 315-326, 1992.

Hauglustaine, D. A., Brasseur, G. P., Walters, S., Rasch, P. J., Müller, J.-F., Emmons, L. K., and Carroll, M. A.: MOZART, a global chemical transport model of ozone and related chemical tracers: 2. Model results and evaluation, J. Geophys. Res., 103, 28 291-28 335, 1998.

Heikes, B. G.: Formaldehyde and hydroperoxides at Mauna Loa Observatory, J. Geophys. Res., 97, 18 0010-18 013, 1992.

Heikes, B., Snow, J., Egli, P., O’Sullivan, D., Crawford, J., Olson, J., Chen, G., Davis, D., Blake, N., and Blake, D.: Formaldehyde over the central Pacific during PEM-Tropics B, J. Geophys. Res., 106, 32 717-32 731, 2001.

Iraci, L. T., Essin, A. M., and Golden, D. M.: Solubility of methanol in low-temperature aqueous sulfuric acid and implications for atmospheric particle composition, J. Phys. Chem. A, 106, 40544060, 2002.

Jacob, D. J., Heikes, B. G., Fan, S.-M., Logan, J. A., Mauzerall, D. L., Bradshaw, J. D., Singh, H. B., Gregory, G. L., Talbot, R. W., Blake, D. R., and Sachse, G. W.: Origin of ozone and $\mathrm{NO}_{\mathrm{x}}$ in the tropical troposphere: A photochemical analysis of aircraft observations over the South Atlantic basin, J. Geophys. Res., 101, 24 235-24 250, 1996.

Jaeglé, L., Jacob, D. J., Brune, W. H., Faloona, I., Tan, D., Heikes, B. G., Kondo, Y., Sachse, G. W., Anderson, B., Gregory, G. L., Singh, H. B., Pueschel, R., Ferry, G., Blake, D. R., and Shetter, R. E.: Photochemistry of $\mathrm{HO}_{\mathrm{x}}$ in the upper troposphere at northern midlatitudes, J.Geophys. Res., 3877-3892, 2000.

Kelly, T. J., and Fortune, C. R.: Continuous monitoring of gaseous formaldehyde using an improved fluorescence approach, Intern.
J. Environ. Anal. Chem., 54, 249-263, 1994.

Lawrence, M. G., Crutzen, P. J., Rasch, P. J., Eaton, B. E., and Mahowald, N. M.: A model for studies of tropospheric photochemistry: Description, global distributions, and evaluation, J. Geophys. Res., 104, 26 245-26 277, 1999.

Lawrence, M. G., Rasch, P. J., von Kuhlmann, R., Williams, J., Fischer, H., de Reus, M., Lelieveld, J., Crutzen, P.J., Schultz, M., Stier, P., Huntrieser, H., Heland, J., Stohl, A., Forster, C., Elbern, H., Jakobs, H., and Dickerson, R. R.: Global chemical weather forecasts for field campaign planning: Predictions and observations of large-scale features during MINOS, CONTRACE, and INDOEX, Atmos. Chem. Phys., 3, 267-289, 2002.

Lee, M., Heikes, B. G., Jacob, D. J., Sachse, G., and Anderson, B.: Hydrogen peroxide, organic peroxides, and formaldehyde as primary pollutants from biomass burning, J. Geophys. Res., 102, 1301-1309, 1997.

Lee, Y.-N., Zhou, X., Kleinmann, L. I., Nunnermacker, L. J., Springston, S. R., Daum, P. H., Newman, L., Keigley, W. G., Holdren, M. W., Spicer, C. W., Young, Y., Fu, B., Parrish, D. D., Holloway, J., Williams, J., Roberts, J. M., Ryerson, T. B., and Fehsenfeld, F. C.: Atmospheric chemistry and distribution of formaldehyde and several multioxygenated carbonyl compounds during the 1995 Nashville/Middle Tennessee Ozone Study, J. Geophys. Res., 103, 22 449-22 462, 1998.

Lelieveld, J., Berresheim, H., Borrmann, S., Crutzen, P. J., Dentener, F. J., Fischer, H., Feichter, J., Flatau, P., Heland, J., Holzinger, R., Kormann, R., Lawrence, M., Levin, Z., Markowicz, K., Mihalopoulos, N., Minikin, A., Ramanathan, V., de Reus, M., Roelofs, G. J., Scheeren, H. A., Sciare, J., Schlager, H., Schultz, M., Siegmund, P., Steil, B., Stephanou, E., Stier, P., Traub, M., Williams, J., and Ziereis, H.: Global air pollution crossroads over the Mediterranean, Science, 298, 794-799, 2002.

Liu, S. C., Trainer, M., Carroll, M. A., Hübler, G., Montzka, D. D., Norton, R. B., Ridley, B. A., Walega, J. G., Atlas, E. L., Heikes, B. G., Huebert, B. J., and Warren, W.: A study of the photochemistry and ozone budget during the Mauna Loa Observatory Experiment, J. Geophys. Res., 97, 10 463-10 471, 1992.

Lowe, D. C. and Schmidt, U.: Formaldehyde (HCHO) measurements in the nonurban atmosphere, J. Geophys. Res., 88, 10844 $10858,1983$.

Macdonald, A. M., Wiebe, H. A., Li, S. M., Dryfhout-Clark, H., Asalian, K., Lu, G., Wang, D., Schiller, C. L., Harris, G. W., Sumner, A. L., and Shepson, P. B.: Results of a formaldehyde intercomparison study in Ontario, Report Nr. ACSD-99-001, Atmospheric Environment Service, Ontario, Canada, 1999.

Mackay, G. I., Karecki, D. R., and Schiff, H. I.: Tunable diode laser absorption measurements of $\mathrm{H}_{2} \mathrm{O}_{2}$ and $\mathrm{HCHO}$ during the Mauna Loa Photochemistry Experiment, J. Geophys. Res., 101, 14721 $14728,1996$.

Nash, T.: The colorimetric estimation of formaldehyde by means of the Hantzsch reaction, Biochemistry, 55, 416-421, 1953.

Platt, U. and Perner, D.: Direct measurements of atmospheric $\mathrm{CH}_{2} \mathrm{O}, \mathrm{HNO}_{2}, \mathrm{O}_{3}, \mathrm{NO}_{2}$, and $\mathrm{SO}_{2}$ by differential optical absorption in the near UV, J. Geophys. Res., 85, 7453-7458, 1980.

Scheeren, H. A., Lelieveld, J., Roelofs, G.-J., Williams, J., Fischer, H., de Reus, M., de Gouw, J. A., Warneke, C., Holzinger, R., Schlager, H., Klüpfel, T., Bolder, M., van der Veen, C., and Lawrence, M.: The impact of monsoon outflow from South-East Asia in the upper troposphere over the eastern Mediterranean, 
Atmos. Chem. Phys. Discuss., 3, 2285-2330, 2003.

Sigsby, J. E., Tejada, S., Ray, W., Lang, M., and Duncan, J. W.: Volatile organic compounds emissions from 46 in-use passenger cars, Environm. Sci. Technol., 21, 466-475, 1987.

Singh, H. B., Chen, Y., Tabazadeh, A., Fukui, Y., Yantosca, R., Jacob, D., Arnold, F., Wohlfrom, K., Atlas, E., Flocke, F., Blake, D., Blake, N., Heikes, B., Snow, J., Talbot, R., Gregory, G., Sachse, G., Vay, S., and Kondo, Y.: Distribution and fate of selected oxygenated organic species in the lower troposphere and lower stratosphere over the Atlantic, J. Geophys. Res., 105, 3795-3805, 2000.

Thomas, E. R., Frost, G. J., and Rudich, Y.: Reactive uptake of ozone by proxies for organic aerosols: Surface-bound and gasphase products, J. Geophys. Res., 106, 3045-3056, 2001.

Traub, M., Fischer, H., de Reus, M., Kormann, R., Heland, J., Ziereis, H., Schlager, H., Holzinger, R., Williams, J., Warneke, C., de Gouw, J., and Lelieveld, J.: Chemical characteristics assigned to trajectory clusters during the MINOS campaign, Atmos. Chem. Phys., 3, 459-468, 2003.

von Kuhlmann, R.: Photochemistry of tropospheric ozone, its precursors and the hydroxyl radical: A 3D-modeling study considering non-methane hydrocarbons, Ph.D. thesis, University of Mainz, Mainz, Germany, 2001.

von Kuhlmann, R., Lawrence, M. G., Crutzen, P. J., and Rasch, P. J.: A model for studies of tropospheric ozone and non-methane hydrocarbons: Model description and ozone results, J. Geophys. Res., in press, 2003a. von Kuhlmann, R., Lawrence, M. G., Crutzen, P. J., and Rasch, P. J.: A model for studies of tropospheric ozone and non-methane hydrocarbons: Model evaluation of ozone related species, J. Geophys. Res., submitted, 2003 b.

Wagner, V., Schiller, C., and Fischer, H.: Formaldehyde measurements in the marine boundary layer of the Indian Ocean during the 1999 INDOEX cruise of the R/V Ronald H. Brown, J. Geophys. Res., 106, 28 529-28 538, 2001.

Wagner, V., von Glasow, R., Fischer, H., and Crutzen, P. J.: Are $\mathrm{CH}_{2} \mathrm{O}$ measurements in the marine boundary layer suitable for testing the current understanding of $\mathrm{CH}_{4}$ photooxidation?: A model study, J. Geophys. Res., 107, D3, 10.1029/2001JD000722, 2002.

Weller, R. O., Schrems, O., Boddenberg, A., Gäb, S., and Gautrois, M.: Meridional distribution of hydroperoxides and formaldehyde in the marine boundary layer of the Atlantic $\left(48^{\circ} \mathrm{N}-35^{\circ} \mathrm{S}\right)$ measured during the Albatross campaign, J. Geophys. Res., 105, 14 401-14 412, 2000.

Wert, B. P., Fried, A., Henry, B., and Cartier, S.: Evaluation of inlets used for the airborne measurement of formaldehyde, J. Geophys. Res., 107, D13, 10.1029/2001JD001072, 2002.

Zafirou, O. C., Alford, J., Herrera, M., Peltzer, E. T., Gagosian, R. B., and Liu, S. C.: Formaldehyde in remote marine air and rain: Flux measurements and estimates, Geophys. Res. Lett., 7, 341344, 1980.

Zhou, X., Lee, Y.-N., Newman, L., Chen, X., and Mopper, K.: Tropospheric formaldehyde concentration at the Mauna Loa Observatory during the Mauna Loa Photochemistry Experiment 2, J. Geophys. Res., 101, 14711-14 719, 1996. 